OPEN ACCESS

Edited by:

Eiii Yoshihara,

Lundquist Institute for Biomedical Innovation, United States

Reviewed by:

Shimpei Fujimoto,

Kōchi University, Japan

Zong Wei,

Mayo Clinic Arizona, United States

*Correspondence:

Nobuya Inagaki

inagaki@kuhp.kyoto-u.ac.jp

Specialty section:

This article was submitted to Diabetes: Molecular Mechanisms, a section of the journal

Frontiers in Endocrinology

Received: 25 May 2021 Accepted: 14 June 2021

Published: 25 June 2021

Citation:

Murakami T, Fujimoto H and Inagaki N

(2021) Non-invasive Beta-cell

Imaging: Visualization,

Quantification, and Beyond.

Front. Endocrinol. 12:714348. doi: 10.3389/fendo.2021.714348

\section{Non-invasive Beta-cell Imaging: Visualization, Quantification, and Beyond}

\author{
Takaaki Murakami ${ }^{1}$, Hiroyuki Fujimoto ${ }^{2}$ and Nobuya Inagaki ${ }^{1 *}$ \\ ${ }^{1}$ Department of Diabetes, Endocrinology and Nutrition, Kyoto University Graduate School of Medicine, Kyoto, Japan, \\ 2 Radioisotope Research Center, Agency of Health, Safety and Environment, Kyoto University, Kyoto, Japan
}

Pancreatic beta $(\beta)$-cell dysfunction and reduced mass play a central role in the development and progression of diabetes mellitus. Conventional histological $\beta$-cell mass $(\mathrm{BCM})$ analysis is invasive and limited to cross-sectional observations in a restricted sampling area. However, the non-invasive evaluation of BCM remains elusive, and practical in vivo and clinical techniques for $\beta$-cell-specific imaging are yet to be established. The lack of such techniques hampers a deeper understanding of the pathophysiological role of $\mathrm{BCM}$ in diabetes, the implementation of personalized BCMbased diabetes management, and the development of antidiabetic therapies targeting BCM preservation and restoration. Nuclear medical techniques have recently triggered a major leap in this field. In particular, radioisotope-labeled probes using exendin peptides that include glucagon-like peptide-1 receptor (GLP-1R) agonist and antagonist have been employed in positron emission tomography and single-photon emission computed tomography. These probes have demonstrated high specificity to $\beta$ cells and provide clear images accurately showing uptake in the pancreas and transplanted islets in preclinical in vivo and clinical studies. One of these probes, ${ }^{111}$ indium-labeled exendin- 4 derivative ([Lys ${ }^{12}\left({ }^{111}\right.$ In-BnDTPA-Ahx)]exendin-4), has captured the longitudinal changes in BCM during the development and progression of diabetes and under antidiabetic therapies in various mouse models of type 1 and type 2 diabetes mellitus. GLP-1R-targeted imaging is therefore a promising tool for non-invasive BCM evaluation. This review focuses on recent advances in non-invasive in vivo $\beta$-cell imaging for BCM evaluation in the field of diabetes; in particular, the exendin-based GLP-1R-targeted nuclear medicine techniques.

Keywords: beta-cell imaging, glucagon-like peptide-1, exendin, positron emission tomography, single photon emission computed tomography, $\beta$-cell mass, islet transplantation, diabetes mellitus

\section{INTRODUCTION}

The number of patients with diabetes worldwide is on the rise. The estimated prevalence of patients with diabetes 20 years of age or older has risen from 151 million to 463 million from 2000 to 2019, and it is predicted to increase to 700 million by 2045 (1). To control this increase, we need a detailed understanding of the pathogenesis of diabetes and to develop new diagnostic strategies and policies for treating the disease. 
The reduction of pancreatic beta $(\beta)$-cell mass (BCM) and $\beta$-cell function involves the onset and progression of diabetes; BCM plays a central role in the pathophysiology of both type 1 and type 2 diabetes mellitus (2-4). In type 1 diabetes mellitus, the time-course patterns of $\beta$-cell destruction vary from the prominent type to latent autoimmune diabetes in adults or slowly progressive insulin-dependent diabetes mellitus (5-7). Residual BCM is therefore an important factor in managing type 1 diabetes mellitus, whereas viable graft islet volume largely affects the outcomes in islet cell transplantation (8). In type 2 diabetes mellitus, substantially reduced BCM is observed, even at diagnosis, and can affect the responsiveness of antidiabetic therapy (3, 9-11). Therefore, a BCM evaluation leads to not only a deeper and more concise understanding of the individual's diabetic state but also the development and evaluation of antidiabetic therapy aimed at BCM restoration and protection. Although conventional methods for evaluating in vivo BCM are difficult for practical use due to their invasiveness and unsatisfactory $\beta$-cell specificity, non-invasive pancreatic $\beta$-cell imaging using nuclear medicine techniques have emerged in recent years. In particular, radioisotope-labeled probes using exendin peptides [including glucagon-like peptide-1 (GLP-1) receptor agonist and antagonist] have been promising tools for positron emission tomography (PET) and single-photon emission computed tomography (SPECT) imaging. A number of these probes, including ${ }^{111}$ indium-labeled exendin-4 derivative $\left\{\left[\right.\right.$ Lys $\left.^{12}\left({ }^{111} \mathrm{In}-\mathrm{BnDTPA}-\mathrm{Ahx}\right)\right]$ exendin- 4$\}$, have demonstrated the visualization of the mouse pancreas and its image analysis for BCM quantification and thereby have shown potential for clinical use (12-15). This review focuses on the recent advances in non-invasive in vivo $\beta$-cell imaging and BCM evaluation for type 1 and type 2 diabetes mellitus, especially exendin-based GLP-1R-targeted nuclear medicine techniques.

\section{THE URGENT NEED FOR NON-INVASIVE $\beta$-CELL MASS EVALUATION IN DIABETES}

Both type 1 and type 2 diabetes mellitus are characterized by a progressive reduction in BCM (16). Although the evaluation of pancreatic $\beta$-cell function is essential for understanding insulin secretion failure, the systemic $\beta$-cell function consists not only of the ability of individual $\beta$ cells to secrete insulin but also the regulation of BCM (Figure 1). However, conventional markers such as plasma and urine C-peptide levels do not provide direct information regarding $\mathrm{BCM}$ and do not discriminate changes in $\mathrm{BCM}$ from those of individual $\beta$-cell function. Therefore, the exact relationship between BCM and $\beta$-cell function in the onset and progression of diabetes remains unclear (17-19). Direct information regarding BCM itself provides a novel parameter for understanding the pathophysiology of diabetes and evaluating the efficacy of new and existing antidiabetic therapy. However, the conventional histological method for evaluating BCM using pancreas samples through autopsy or surgery is invasive and is limited to cross-sectional observations (20). This method also raises certain concerns in terms of the restricted sampling area and staining evenness in view of representing the BCM of the entire pancreas (20). A novel technique for noninvasive $\mathrm{BCM}$ monitoring is therefore an urgent need in basic research and clinical fields.

In type 1 diabetes mellitus, pancreatic $\beta$ cells are predominantly destroyed by autoimmune attacks, which result in markedly

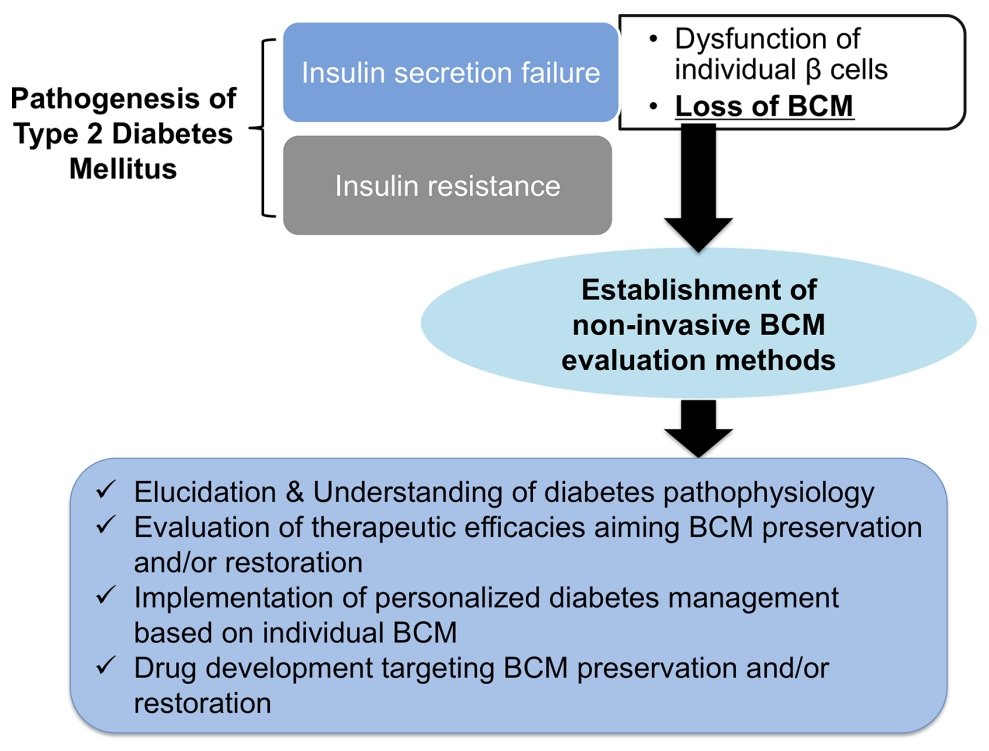

FIGURE 1 | The expected benefits of non-invasive $\beta$-cell mass (BCM) evaluation. Loss of BCM has a central role in the onset and progression of type 2 diabetes mellitus. The establishment of non-invasive BCM evaluation methods will open the door to elucidating and understanding the pathophysiology of diabetes, the evaluation of therapeutic efficacies aimed at preserving and restoring BCM, the implementation of personalized diabetes management based on individual BCM, and drug development targeting BCM preservation and restoration. 
reduced BCM and severe insulin deficiency. However, the remaining viable $\beta$ cells, including non-functional ones, are observed in over $30 \%$ of patients with long-duration type 1 diabetes mellitus $(18,21,22)$. Moreover, slices of pancreatic tissue from organ donors with type 1 diabetes mellitus revealed that BCM loss might be preceded by a decline in $\beta$-cell function and have a varying contribution to the pathogenesis of type 1 diabetes mellitus (23). Recent studies have revealed that certain patients present with slowly progressive types of type 1 diabetes mellitus, such as latent autoimmune diabetes in adults and slowly progressive insulin-dependent diabetes mellitus, in which systemic $\beta$-cell function is persistently preserved, although the natural history of BCM changes in these types remains to be investigated (5-7). These findings suggest the range of remaining $\mathrm{BCM}$ in individuals with type 1 diabetes mellitus and increase the clinical importance of evaluating BCM. In addition, $\mathrm{BCM}$ can be a potential target for preservation and restoration in future therapeutic interventions for type 1 diabetes mellitus. A $\mathrm{BCM}$ evaluation is therefore essential for broadening the insights into its pathophysiology and developing a new therapeutic strategy for type 1 diabetes mellitus.

Islet transplantation, in which isolated donor islets are infused into the portal vein, has become a promising treatment option for patients with type 1 diabetes mellitus $(24,25)$. Although islet transplantation can improve glycemic control and even achieve insulin independence $(25,26)$, a sufficient volume of islet grafts is required to achieve insulin independence. The posttransplantation loss of islet grafts is often observed, which might require repeated islet transplantations $(8,26,27)$. A non-invasive imaging method is therefore needed to monitor these islets over time. Stem-cell-derived transplantation, encapsulation devices, and subcutaneous implantation have received significant attention recently as approaches for solving the problem of lack of donors and to minimalize invasiveness $(26,28-30)$. Non-invasive $\beta$-cell imaging is useful for evaluating and improving the efficacy of these techniques.

In type 2 diabetes mellitus, a hypothetic model of BCM changes has been proposed; type 2 diabetes mellitus occurs in response to a reduction in $\mathrm{BCM}$ following a temporary compensatory increase in BCM induced by obesity and insulin resistance. BCM subsequently decreases progressively $(2,3)$. This hypothetic model is, however, simply a patchwork model based on the implications of cross-sectional studies, given that the method for evaluating BCM has been limited to a pathological type, using surgically resected or postmortem pancreatic samples (20). Butler AE et al. investigated BCM using post-mortem pancreatic sections and reported that BCM in type 2 diabetes mellitus was reduced by $63 \%$ in cases of obesity and by $41 \%$ in cases without obesity compared with those cases with normal glucose tolerance (10). Interestingly, BCM in impaired fasting glucose conditions also showed an approximately $40 \%$ reduction compared with that in healthy participants (10). In other autopsy studies of Asian populations such as Japan and South Korea, a $30-50 \%$ reduction in BCM was observed in patients with type 2 diabetes mellitus compared with those with normal glucose tolerance $(31,32)$. These reports suggest that the onset and progression of type 2 diabetes mellitus is involved not only in the decline in $\beta$-cell function but also in the reduction in BCM (33, 34). In this context, preserving or restoring BCM is a critical strategy for the prevention and long-term management of the disease $(3,9)$. Moreover, individual BCM information can provide a chance to optimize antidiabetic therapy individually, which can open the door to truly personalized precision medicine in the field of diabetes. The elucidation of the individual's remaining $\mathrm{BCM}$ and the effects of antidiabetic agents on BCM is of significant value $(20,35)$. These studies also raise the clinical issue that a non-negligible reduction in BCM might have already occurred by the time type 2 diabetes mellitus is clinically diagnosed $(10,20)$. To address this unmet clinical need, an earlier recognition and monitoring of BCM changes are essential for preventing and preemptively managing type 2 diabetes mellitus. Urgent needs for non-invasive BCM evaluation should therefore be noted (Figure 1).

\section{CHALLENGES OF NON-INVASIVE $\beta$-CELL-SPECIFIC IMAGING}

Despite the need for and the potential of non-invasive $\beta$-cell imaging and quantification, the feasibility of such technologies has been hampered by numerous obstacles, one of which is the small and scattered area comprising $\beta$ cells in the total pancreas. Pancreatic $\beta$ cells constitute only $1-3 \%$ of the total pancreatic mass. $\beta$ cells also constitute the islets of Langerhans, which are heterogeneously distributed throughout the pancreas and are composed of various other cell types such as alpha, delta, and pancreatic polypeptide cells $(34,36)$. Another major obstacle is the spatial resolution of clinical imaging modalities, given that the islets of Langerhans are approximately $40-300 \mu \mathrm{m}$ in diameter. In vivo $\beta$-cell visualization and quantification require imaging modalities with sufficiently high spatial resolution to image individual islets, and no widely available clinical modality [including computed tomography (CT) and magnetic resonance imaging (MRI)] has satisfied this requirement (17). Therefore, instead of resolving single islets, the strategy has been to measure total pancreas signals from tracer molecules highly specific to $\beta$ cells and provide an estimated BCM. In this context, nuclear medicine imaging techniques such as SPECT and PET have attracted attention $(20,37)$ due to their ability to detect their radioisotope-labeled probes at picomolar ranges, despite their limited spatial resolutions (38). The high specificity to $\beta$ cells of high-sensitivity imaging modalities combined with radioisotopelabeled probes outweighs the shortcomings of their spatial resolution $(17,39)$. Accordingly, SPECT and PET have been investigated for the application to in vivo $\beta$-cell-specific imaging.

\section{EXPLORATION OF IDEAL PROBE TARGETS IN IN VIVO $\beta$-CELL IMAGING}

The identification of ideal probe targets highly specific to $\beta$ cells is essential for performing $\beta$-cell SPECT and PET imaging. 
Therefore, the various molecules whose expression is observed specifically in $\beta$ cells have been explored, and those ligands, substrates, and antibodies have been investigated as putative probes for $\beta$-cell imaging. To date, sulfonylurea receptor 1 (SUR1) $(40,41)$, glucose transporter 2 (42), voltage-dependent calcium channel (43), G protein-coupled receptor 44 (GPR44) $(44,45)$, D2 and D3 dopamine receptors $(46,47)$, serotonergic system (48-51), vesicular monoamine transporter 2 (VMAT2) (52, 53), and GLP-1 receptor (GLP-1R) $(54,55)$ have been reported as potential probe targets (Figure 2) (56).

SUR1 is a subunit of ATP-dependent potassium channels and is specifically expressed in $\beta$ cells except in the brain. Given that sulfonylureas are known for their binding affinities to SUR1 and in light of their clinical use experience, a number of radiolabeled sulfonylurea derivatives such as glibenclamide and glipizide have been investigated. However, these probes have failed to achieve sufficient specificity to $\beta$ cells; low accumulations in the pancreas and high background signals $(57,58)$. Although a mitiglinide derivative has been reported as a potential $\beta$-cell imaging probe with higher specificity (40), none of the available probes targeting SUR1 are currently feasible.

D2 and D3 dopamine receptors involve glucose-stimulated insulin secretion in $\beta$ cells (59) and have been suggested as a target for $\beta$-cell imaging (46). PET imaging with the receptor agonist $3,4,4 \mathrm{a}, 5,6,10 \mathrm{~b}$-hexahydro-2H-naphtho(1,2-b) $(1,4)$ oxazin-9-ol was examined in patients with type 1 diabetes mellitus (46), demonstrating reasonable pancreatic uptake and non-negligible uptake in the spleen, located near the tail of the pancreas. A substantial overlapping of probe accumulations in the pancreas has been observed between patients with type 1 diabetes mellitus and healthy participants (46). Another probe, $\left[{ }^{18} \mathrm{~F}\right]$ dihydroxyphenylalanine $\left[\left({ }^{18} \mathrm{~F}\right) \mathrm{DOPA}\right]$, has been investigated for nesidioblastosis, with several groups reporting the successful imaging of responsible foci. However, $\left[{ }^{18} \mathrm{~F}\right] \mathrm{DOPA}$ was taken up in both endocrine and exocrine pancreatic cells and showed high background signals, which suggests a limited potential use for this probe (60).

$\left({ }^{11} \mathrm{C}\right) 5$-hydroxytryptophane $\left[\left({ }^{11} \mathrm{C}\right) \mathrm{HTP}\right]$ is a tracer employed for evaluating serotonin biosynthesis and is metabolized by dopamine decarboxylase to $\left({ }^{11} \mathrm{C}\right)$ serotonin. Given that serotonin is accumulated in $\beta$ cells, $\left[{ }^{11} \mathrm{C}\right] \mathrm{HTP}$ PET has been investigated in $\beta$-cell imaging, demonstrating substantially reduced accumulation in the pancreas of patients with type 1 diabetes mellitus (48). $\left({ }^{11} \mathrm{C}\right) \mathrm{HTP}$ PET also demonstrated its potential utility for the longitudinal observation of islet mass in type 1 diabetes mellitus and islet transplantation $(49,51)$. However, conflicting reports have suggested that HTP is accumulated in other pancreatic endocrine and exocrine cells and have encountered difficulties in distinguishing BCM between healthy participants and patients with diabetes due to the large overlap $(17,61,62)$.

VMAT2 is an integral membrane protein for neurotransmitter transport. The derivatives of dihydrotetrabenazine (DTBZ), a ligand of VMAT2, have been actively researched as potential

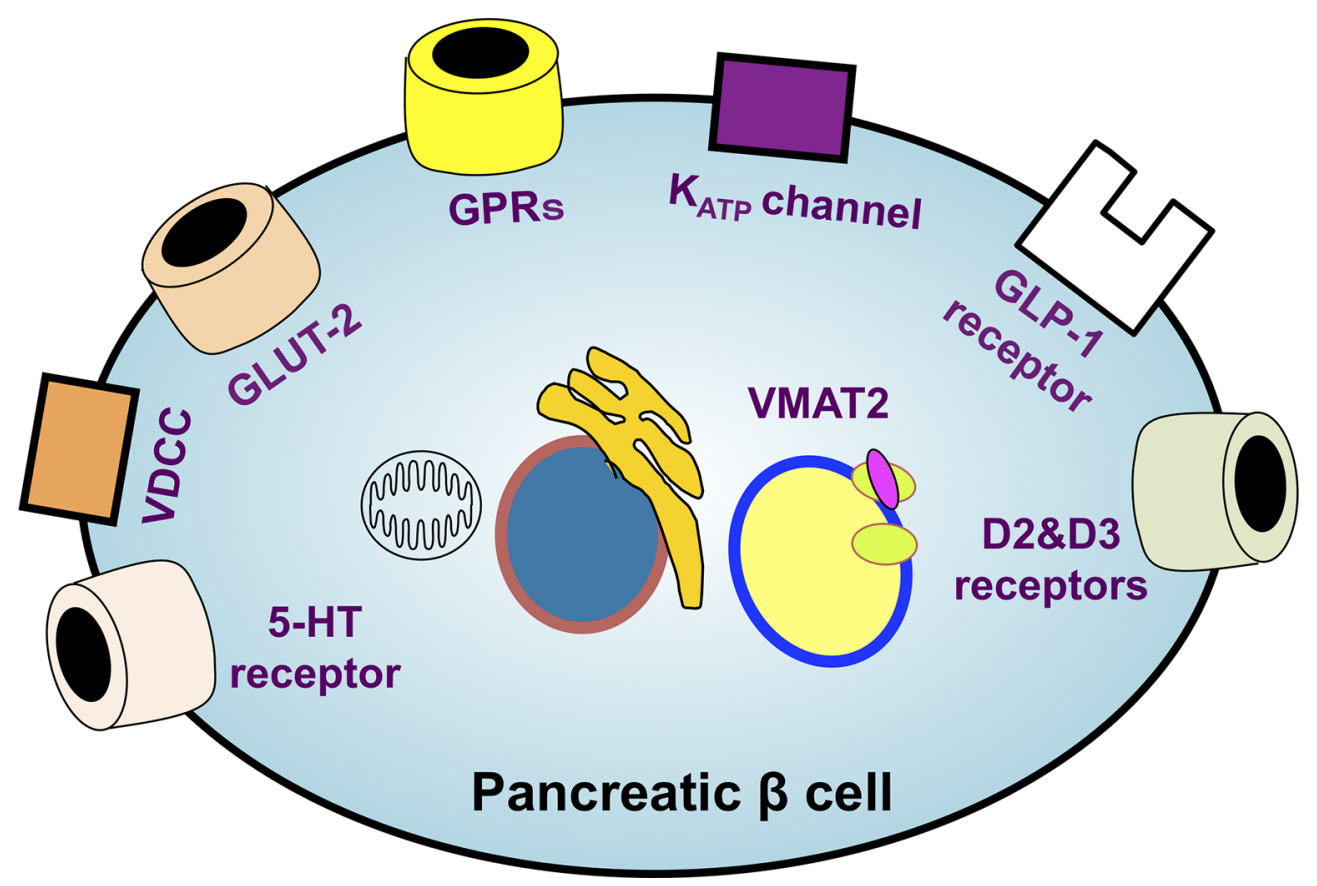

FIGURE 2 | An overview of the potential targets of $\beta$-cell-specific imaging probes. The identification of ideal probe targets highly specific to $\beta$ cells is essential for realizing $\beta$-cell imaging. The various molecules whose expression is observed specifically in $\beta$ cells have been explored. SUR1, glucose transporter 2 (GLUT-2), voltage-dependent calcium channel (VDCC), G protein-coupled receptors (GPRs), D2 and D3 dopamine receptors, serotonergic system, vesicular monoamine transporter 2 (VMAT2), and GLP-1 receptors have been reported as leading potential probe targets. K $^{\text {ATP }}$ channel, ATP-sensitive potassium channel; 5-HT receptor, 5-hydroxytryptamine receptor. 
$\beta$-cell imaging probes. However, most DTBZ derivatives have demonstrated high exocrine-islet ratios in the pancreas, lacking the specific accumulation in $\beta$ cells. $\left({ }^{18} \mathrm{~F}\right)$ fluoropropyl-DTBZ has been employed for evaluating BCM in patients with type 1 diabetes, showing lower accumulations in the pancreas compared with those of healthy participants (52). However, non-specific binding was observed not only in the liver and spleen but also in the pancreas, which could significantly affect the accuracy of the BCM evaluation and could overestimate BCM (52). Most signals of the DTBZ-related probes originated from delta and PP cells, which also expressed VMAT2, and this nonspecific binding was higher in patients with diabetes $(52,63,64)$. These probes should therefore be further optimized for BCM evaluation.

\section{VISUALIZATION OF $\beta$ CELLS: GLUCAGON- LIKE PEPTIDE-1 RECEPTOR-TARGETED IMAGING}

GLP-1R is a G-protein-coupled receptor that plays a key role in glucose metabolism and is a major therapeutic target for diabetes. GLP-1R is considerably expressed in $\beta$ cells, whereas its expression level in other endocrine cells has been reported as absent or low (65). GLP-1R expression in pancreatic exocrine cells is low in humans, although certain animal models such as pigs exhibit relatively high GLP-1R expression in the exocrine pancreas (66). GLP-1R has therefore been the most actively investigated viable target of $\beta$-cell imaging probes.

GLP-1, an endogenous GLP-1R ligand peptide, ameliorates glucose-dependent insulin secretion, whereas having a very short plasma half-life due to the rapid degradation by dipeptidyl peptidase-4 (67). In line with efforts to improve the in vivo stability against dipeptidyl peptidase-4, exendin peptides (originally found in the saliva of Heloderma suspectum) have been synthesized and have shown high in vivo stability with a high affinity to GLP-1R (68). Whereas exendin (9-39) is a GLP-1 antagonist, exendin-3 and exendin-4 are GLP-1R agonists. Exendin-4 differs from exendin- 3 by two amino acid substitutions (Gly2-Glu3 in place of Ser2-Asp3) but is otherwise identical (Figure 3). Moreover, exendin-4 has been successfully employed in the clinical treatment of type 2 diabetes mellitus, which qualified the potential clinical stability and safety of exendin-based probes for $\beta$-cell imaging. Exendin-related peptides, especially exendin-4, have therefore become the lead compounds in the development of GLP-1R-targeted probes for $\beta$-cell imaging, and various modified peptides have been investigated as potential imaging probes.

As for in vivo $\beta$-cell visualization, the pioneer study with exendin-based probe for GLP-1R was reported with radioiodinated exendin-3 (69). Biodistribution studies of $\left[{ }^{123} \mathrm{I}\right]$ exendin-3 in rats harboring rat insulinoma cells (RINm5F) have shown rapid blood clearance and uptake of the radiotracer into the tumor and pancreas, which could be detected by SPECT. ${ }^{111}$ In-labeled exendin-3, $\left\{\right.$ Lys $^{40}\left[\left({ }^{111}\right.\right.$ In $)$ DTPA $\left.]\right\}$ exendin-3, was subsequently synthesized, given that the high sensitivity of ${ }^{111}$ In-labeled tracers allowed for the administration of small amounts of tracer to prevent receptor saturation and adverse effects in SPECT (70). In a controlled, unilaterally nephrectomized mouse study, autoradiography showed the specific uptake of $\left\{\right.$ Lys $\left.^{40}\left[\left({ }^{111} \mathrm{In}\right) \mathrm{DTPA}\right]\right\}$ exendin-3 in insulinexpressing cells, with the highest uptake in the pancreas and lungs followed by the kidneys (71). In another study, diabetic rats showed ${ }^{111}$ In- $\left[\right.$ Lys $^{40}$ ] exendin-3 uptake in the pancreas (12). ${ }^{68}$ Gallium (Ga)-labeled exendin-3 has also been developed as a probe for PET imaging (72). In most of the designs of exendin-3 probes for SPECT and PET, the residue Lys ${ }^{40}$ of exendin- 3 was conjugated with the radioisotope-labeling structures. Although exendin-3 probes showed successful in vivo visualization of the pancreas, further research to improve the stability is warranted (39).

Subsequently, exendin (9-39) also has been expected as a potent skeleton of GLP-1R-targeted probe for $\beta$-cell imaging, and its derivatives have been investigated. One of the considerable advantages of exendin (9-39) is its ability to avoid hypoglycemia due to GLP-1R activation. A preclinical study of ${ }^{125}$ Iodine-BoltonHunter ( $\left.\left[{ }^{125} \mathrm{I}\right] \mathrm{BH}\right)$-labeled exendin (9-39) exhibited good affinity to GLP-1R and high uptake in mice pancreas (54). However, the uptake in pancreatic $\beta$ cells might be species-dependent because the pancreatic uptake of $\left({ }^{125} \mathrm{I}\right) \mathrm{BH}$-exendin (9-39) differed in human and mouse tissues (73). Based on the influence of the $\mathrm{BH}$ labeling site on the target properties, $\mathrm{BH}$ labeling on $\mathrm{Lys}^{19}$ showed comparable affinity in human and rat tissues (74). In addition, a moiety of $\left({ }^{111} \mathrm{In}\right)$ diethylenetriaminepentaacetic acid (DTPA) or tetraazacyclododecane

$\begin{array}{lll} & 1 & 12 \\ \text { hGLP-1 } & \text { HAEGTFTSDVSSYLEGQAAKEFIAWLVKGR-NH2 } & 39 \\ \text { Exendin-3 } & \text { HSDGTFTSDLSKQMEEEAVRLFIEWLKNGGPSSGAPPPS-NH2 } \\ \text { Exendin-4 } & \text { HGEGTFTSDLSKQMEEEAVRLFIEWLKNGGPSSGAPPPS-NH2 } \\ \text { Exendin(9-39) } & \text { DLSKQMEEEAVRLFIEWLKNGGPSSGAPPPS-NH2 }\end{array}$

FIGURE 3 | An overview of the leading compounds for GLP-1R-targeted probes. In the development of GLP-1R-targeted imaging probes, exendin-related peptides such as exendin-3, exendin-4, and exendin (9-39) have been investigated as promising compounds. These compounds have approximately $50 \%$ homology with human GLP-1 (hGLP-1) and show high stability in vivo and high affinity to GLP-1R, which qualifies their potential as tracers for in vivo $\beta$-cell imaging. Exendin-4 differs from exendin-3 by two amino acid substitutions (in orange). C-terminally modified derivatives tended to show superior specificity, whereas the modified derivatives on the residue Lys ${ }^{12}$ of exendin-4 (in blue) demonstrated high affinity to GLP-1R and in vivo stability as in vivo imaging probes for $\beta$ cells. 
tetraacetic acid (DOTA) via aminohexanoic acid linker (Ahx) has been introduced to obtain clearer SPECT images of the pancreas. In accordance with $\left({ }^{125} \mathrm{I}\right) \mathrm{BH}$ reagents, partial modifications of exendin (9-39) at lysine residues and the N-terminus have been considered in the development of [ ${ }^{111}$ In]DTPA-labeled derivatives (75). However, a crystal structure analysis suggested that modification of the lysine at position 27 would not improve the imaging of GLP-1R-positive tissues $(75,76) .{ }^{111}$ In-[Lys ${ }^{40}$ (Ahx-DTPA)NH2] exendin (9-39) probe showed reasonable affinity to GLP-1R in vitro, whereas a biodistribution study demonstrated low specific uptake without efficient retention or internalization of the probe, with lower accumulation in rat insulinoma INS-1 tumors and lower INS-1 tumor/pancreas contrast ratio compared with GLP-1R agonist-based counterparts (77). ( ${ }^{111}$ In)benzyl (Bn)DTPA-exendin (9-39) demonstrated higher affinity for GLP-1R compared with its parent compound, exendin (9-39), and clearly visualized INS-1 tumors in mice (75). Compared with ${ }^{111} \mathrm{In}\left[\mathrm{Lys}^{40}\right.$ (Ahx-DTPA)NH2] exendin (9-39), higher levels of tumor accumulation and uptake ratios between tumors and surrounding organs were observed in a biodistribution study involving INS-1 tumor-bearing mice (75). As for PET imaging, fluorobenzoyl (FB)-modified exendin (9-39) derivatives have been synthesized $(15,78) .\left({ }^{18} \mathrm{~F}\right) \mathrm{FB} 40$-exendin $(9-39)$ showed moderate affinity to GLP-1R, visualized the mouse pancreas, and exhibited superior potentials to other ${ }^{18} \mathrm{~F}$-labeled exendin (9-39) derivatives on different conjugating sites (Lys ${ }^{12}$ and Lys ${ }^{27}$ ) (15). Further enhancement of pancreatic uptake and specific binding to GLP-1R will lead to a clearer visualization of pancreatic $\beta$ cells in exendin (9-39)based PET imaging (15).

Exendin-4 has been the most promising compound in the development of GLP-1R-targeted probes for $\beta$-cell imaging. Although various modifications of exendin- 4 have been investigated, the representative potent exendin-4-based probes are those with the modification of lysine at position 12 and those with the C-terminal modification of adding a lysine at position 40 for SPECT imaging $(12,14)$. $\left[\right.$ Lys $^{40}$ (Ahx-DTPA- ${ }^{111}$ In)NH2] exendin-4 exhibited higher and more stable uptake in the murine pancreas compared with ${ }^{111} \mathrm{In}$-[Lys ${ }^{40}$ (Ahx-DTPA)NH2] exendin (9-39) and visualized the pancreas with SPECT in healthy participants and patients with type 1 diabetes mellitus $(12,77)$. A clinical study employed [Lys ${ }^{40}$ (Ahx-DTPA- ${ }^{111}$ In)NH2] exendin-4 to detect insulinoma and showed successful visualization and clinical safety in patients with insulinoma (79). $\left\{\right.$ Lys $^{40}$ [Ahx-hydrazinonicotinamide (HYNIC)- $\left.{ }^{99 \mathrm{~m}} \mathrm{Tc}\right]$ $\mathrm{NH} 2$ \}exendin-4 was also developed as an alternative to [Lys ${ }^{40}$ (Ahx-DTPA- ${ }^{111}$ In)NH2] exendin-4 (80). Separately, Jodal et al. reported on the use of ${ }^{68} \mathrm{Ga}$-labeled exendin- 4 with a chelator, 1-(1,3-carboxypropyl)-1,4,7-triazacyclononane-4,7-diacetic acid (NODAGA) (81). The conjugation of the chelator to resident lysines at position 12 or the C-terminally attached lysines at position 40 resulted in favorable binding and kinetics for the peptide, in accordance with their high specific uptake in GLP1R-positive murine tissues. Interestingly, the authors also reported that $\left\{\mathrm{Lys}^{12}\left[\left({ }^{68} \mathrm{Ga}\right)\right.\right.$ NODAGA $]$ exendin-4 was more stable than $\left\{\mathrm{Lys}^{40}\left[\left({ }^{68} \mathrm{Ga}\right)\right.\right.$ NODAGA $\left.]\right\}$ exendin-4 in human blood plasma. In this context, an exendin-4 derivative labeled with ${ }^{111}$ In via BnDTPA and Ahx attached to the epsilon amino group at the lysine-12 residue, [Lys ${ }^{12}\left({ }^{111} \mathrm{In}-\mathrm{BnDTPA}-\mathrm{Ahx}\right)$ ] exendin-4, has been synthesized (Figure 4A) (14). This probe has a high affinity for GLP-1R, and the introduction of InBnDTPA at lysine 12 does not affect the affinity for GLP-1R. The radiochemical purity exceeded $95 \%$, and specific activity at the end of synthesis was superior to that of the ${ }^{111}$ In-labeled exendin-3 derivative $(12,14)$. A preclinical biodistribution study of $\left[\right.$ Lys $^{12}\left({ }^{111}\right.$ In-BnDTPA-Ahx) $]$ exendin-4 showed higher and more stable murine pancreatic uptake compared with $\left[{ }^{111} \mathrm{In}\right]$ BnDTPA-exendin (9-39) $(14,75)$. In addition to good pancreatic uptake with probe internalization, low probe uptake and rapid clearance in the surrounding organs (including the liver and kidneys) are desirable properties for in vivo $\beta$-cell imaging probes $(14,77)$. For $\left[\right.$ Lys $^{12}\left({ }^{111}\right.$ In-BnDTPA-Ahx $)$ exendin-4, the pancreas-to-liver uptake ratios increased in a time-dependent manner, and the pancreas-to-kidney uptake ratios remained stable, which enhanced the contrast and allowed for clear visualization of the murine pancreas in SPECT images (Figure 4B) (14).

As for PET imaging, ${ }^{68} \mathrm{Ga},{ }^{18} \mathrm{~F},{ }^{64} \mathrm{Cu}$, and zirconium-89 $\left({ }^{89} \mathrm{Zr}\right.$ )-labeled exendin-4 derivatives have been developed (39). In particular, ${ }^{68} \mathrm{Ga}$-labeled exendin- 4 derivatives have been well researched in preclinical and clinical studies, with the goal of overcoming the low spatial resolution and relatively high kidney uptake of SPECT probes by using ${ }^{68} \mathrm{Ga}$ for PET imaging. In addition to NODAGA (81), several chelator moieties such as DOTA, 1,4,7-triazacyclononane-triacetic acid (NOTA), and desferrioxamine $\mathrm{B}$ (DFO) have been conjugated to exendin-4 at various positions. [Lys ${ }^{40}\left(\mathrm{Ahx}-\mathrm{DOTA}-{ }^{68} \mathrm{Ga}\right) \mathrm{NH} 2$ ] exendin-4 showed significant uptake in insulinomas developed in RipTag2 mice and proved to be a potential alternative to [Lys $^{40}$ (Ahx-DTPA- ${ }^{111}$ In)NH2] exendin-4 (80). Exendin-4 peptide radioiodinated at $\mathrm{Tyr}^{40}$ side by side with $\left[\mathrm{Nle}^{14}\right.$, $\mathrm{Lys}^{40}$ (Ahx-DOTA- ${ }^{68} \mathrm{Ga}$ )NH2] exendin-4 showed high binding to INS1 cells and fast internalization kinetics, yielding in vivo tumor visualization in mice bearing INS-1 xenografts (82). A similar peptide, ${ }^{68} \mathrm{Ga}$-DO3A-VS-Cys ${ }^{40}$-exendin-4, also demonstrated GLP-1R-mediated accumulation in the pancreas of rats and cynomolgus monkeys (83). As for NOTA conjugation, an exendin-4 derivative comprising leucine at position 14 and NOTA-conjugated Met-Val-Lys (MVL) sequence with $\mathrm{Cys}^{40}$ $\left(\left[{ }^{68} \mathrm{Ga}\right]\right.$ NOTA-MVK-Cys $\left.{ }^{40}-\mathrm{Leu}^{14}\right)$ exendin-4 showed comparable tumor uptake and reduced kidney uptake in INS-1 mouse xenografts to that of a control agent without the cleavable MVL sequence (84). Similarly, $\left[\mathrm{Lys}^{40}\left(\mathrm{Ahx}-\mathrm{DFO}-{ }^{68} \mathrm{Ga}\right) \mathrm{NH} 2\right]$ exendin-4 demonstrated high serum stability and high and specific in vivo accumulation in mice bearing RINm5f xenografts (85). Several clinical studies have been conducted using ${ }^{68} \mathrm{Ga}$-labeled exendin-4 derivatives, mainly for the purpose of detecting insulinoma, and have reported successful visualization of insulinomas and acceptable clinical safety (86-89). The potential benefits of radioisotopes with longer half-lives have been investigated using ${ }^{64} \mathrm{Cu}$ (half-life, $12.8 \mathrm{~h}$ ) and ${ }^{89} \mathrm{Zr}$ (half-life, 78.4h). Although ${ }^{64} \mathrm{Cu}-\mathrm{DO} 3 \mathrm{~A}-\mathrm{VS}$-Cys ${ }^{40}$ exendin-4 showed strong accumulation in INS-1 xenografts and transplanted islets $(90),\left[{ }^{64} \mathrm{Cu}\right]$ NODAGA-exendin-4 failed 
A

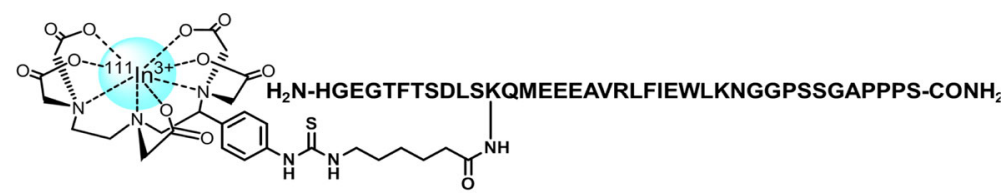

B

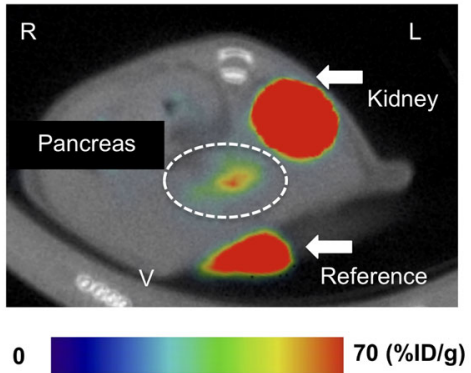

FIGURE 4 | An ${ }^{111}$ Indium(In)-labeled exendin-4 derivative: [Lys ${ }^{12}\left({ }^{111}\right.$ In-BnDTPA-Ahx)]exendin-4. (A) Chemical structure of $\left[\right.$ Lys ${ }^{12}\left({ }^{111}\right.$ In-BnDTPA-Ahx)]exendin-4. Exendin-4 was labeled with ${ }^{111}$ In via isothiocyanate-benzyl-diethylenetriaminepentaacetic acid (BnDTPA) and 6-aminohexanoic (Ahx) attached to the epsilon amino group at the lysine-12 residue. (B) Representative in vivo axial abdominal image of [Lys ${ }^{12}\left({ }^{111}\right.$ In-BnDTPA-Ahx)]exendin-4 single-photon emission computed tomography (SPECT)/computed tomography (CT) in a mouse. [Lys ${ }^{12}\left({ }^{111}\right.$ In-BnDTPA-Ahx)] exendin-4 successfully visualized the pancreas (white dotted circle). Maximum to minimum SPECT intensity: red > orange > yellow > green > blue > black. R, right; L, left; V, ventral.

to visualize the murine pancreas in in vivo PET imaging due to high kidney and liver uptake (91). The other chemical modifications with ${ }^{64} \mathrm{Cu}$ labeling still have difficulties avoiding high kidney and liver uptake (92). As for ${ }^{89} \mathrm{Zr}$, [Lys ${ }^{40}$ (AhxDFO- $\left.{ }^{89} \mathrm{Zr}\right) \mathrm{NH} 2$ ] exendin-4 showed comparable biological performance with $\left[\mathrm{Lys}^{40}\left(\mathrm{Ahx}-\mathrm{DFO}-{ }^{68} \mathrm{Ga}\right) \mathrm{NH} 2\right.$ ] exendin-4, whereas $\left[\mathrm{Lys}^{40}\left(\mathrm{Ahx}-\mathrm{DFO}-{ }^{89} \mathrm{Zr}\right) \mathrm{NH} 2\right.$ ] exendin-4 revealed long kidney retention times (85). In this context, fluorine-18 appears to be one of the most favorable radioisotopes for nuclear medicine imaging due to its positron emission energy and potential for high resolution and widespread use in current clinical settings $(93,94)$. However, preclinical and clinical studies of ${ }^{18}$ F-labeled exendin-4 derivatives are still relatively limited (94). Against expectations, most previous reports on ${ }^{8} \mathrm{~F}$-labeled exendin-4 derivatives have demonstrated high non-specific uptake even in the kidneys $(39,89,94)$. For example, $\left[{ }^{18} \mathrm{~F}\right] \mathrm{FB}-$ exendin-4 showed relatively high liver and kidney uptake, leading to low contrast in in vivo PET images (95). Several potential strategies for reducing non-specific uptake and kidney uptake have therefore been discussed, including the incorporation of highly lipophilic groups, albumin and albumin-binding domains, and nanoparticles (94, 96-98). Certain modifications such as $\left[{ }^{18} \mathrm{~F}\right]$ fluoropentyl maleimide (FPenM)-[Cys $\left.{ }^{40}\right]$ exendin-4 and $\left[{ }^{18} \mathrm{~F}\right]$ fluoronicotinamide (FNEM)- $\left[\mathrm{Cys}^{40}\right]$ exendin-4 have improved renal clearance and tumor-to-kidney contrast in mice bearing INS-1 tumors $(93,99)$. Exendin-4 conjugated with polyethylene glycol might prove to be a promising alternative, given that PEGylation is a wellestablished technique for increasing the probe's molecular weight and stability in circulation and for improving its specific uptake (100).

\section{QUANTIFICATION OF $\beta$-CELL MASS USING GLUCAGON-LIKE PEPTIDE-1R- TARGETED IMAGING}

Advances in GLP-1R-targeted imaging have opened the door to non-invasive BCM quantification in the whole intact pancreas, representing a breakthrough in uncovering the pathophysiology of diabetes mellitus and guiding the development of novel therapeutic strategies in diabetes. Non-invasive BCM quantification methods have been investigated based on the use of probes achieving successful visualization of pancreatic $\beta$ cells. Consequently, these studies have been performed primarily as preclinical studies using small animals and SPECT imaging with ${ }^{111}$ In-labeled probes (11-13, 35, 101-103). Although SPECT appears to present drawbacks in in vivo quantification analysis due to the decay and diffusion of its low-energy gamma rays, recent studies have demonstrated that SPECT could yield sufficient quantitative information, especially in rodents $(12,13$, 101, 102).

${ }^{111}$ In-labeled exendin-3 derivatives have been reported as useful for quantifying rat BCM with ex vivo SPECT scans of resected pancreata $(12,103)$. In Brown Norway rats with and without alloxan treatment, ${ }^{111}$ In- $\left[\right.$ Lys $\left.^{40}\right]$ exendin-3 demonstrated a good correlation between pancreatic uptake (determined by the quantitative analysis of SPECT scans) and BCM (determined by the histological analysis of immunohistological staining with insulin antibodies $)(r=0.83)(12)$. Similarly, $\left[\right.$ Lys ${ }^{40}\left(\left[{ }^{111} \mathrm{In}\right]\right.$ DTPA)] exendin-3 showed a distinctively different uptake in resected pancreas between healthy and alloxan-treated diabetic Brown Norway rats. The ex vivo pancreatic uptake of [Lys ${ }^{40}$ ([ ${ }^{111}$ In]DTPA) ] exendin-3 determined by SPECT showed linear 
correlations with histological BCM $\left(\mathrm{r}^{2}=0.52\right)$ and with BCM based on optical projection tomography $\left(r^{2}=0.77\right)$ (104). Importantly, the probe's pancreatic uptake was not correlated with alpha cell mass (105). Moreover, severe insulitis and hyperglycemia did not affect the linear correlation between the pancreatic probe uptake and histological BCM in nonobese diabetic (NOD) mice (106). Although mice were reported to show relatively higher exendin uptake in the exocrine pancreas compared with rats $(66,107)$, [Lys ${ }^{12}\left({ }^{111}\right.$ In-BnDTPA-Ahx $\left.)\right]$ exendin-4 demonstrated good linear correlations between ex vivo pancreatic uptake and histological BCM in several diabetic model mouse strains such as NOD $(\mathrm{r}=0.90)(102), \mathrm{db} / \mathrm{db}(35)$, and RCS-10 mice $\left(\mathrm{r}^{2}=0.75\right)(11)$. These ${ }^{111}$ In-labeled exendin-3 and exendin-4 derivatives can therefore be promising probes for $\mathrm{BCM}$ quantification using ex vivo SPECT imaging.

However, ex vivo SPECT scans for BCM quantification can provide only limited opportunities for BCM observation during an individual's lifetime and are invasive for obtaining pancreatic samples. Establishing an in vivo SPECT analysis method for BCM quantification is therefore essential for performing non-invasive $\mathrm{BCM}$ evaluations. Analyzing in vivo rodent SPECT images is more difficult than with ex vivo images due to two factors: indistinguishable pancreatic margins in CT images and the influence of renal probe uptake on the analysis of pancreatic regions of interest (101). To solve these issues, several attempts have been examined in addition to various chemical modifications on exendin skeletons to reduce renal uptake as described in the previous section Visualization of $\beta$ cells: Glucagon-like peptide-1 receptor-targeted imaging. Mathijs et al. performed unilateral nephrectomy prior to SPECT scans to reduce the influence from the left kidney in rats (71). According to this protocol, [ $\operatorname{Lys}^{40}\left(\left[{ }^{111} \mathrm{In}\right]\right.$ DTPA)] exendin-3 showed a good correlation between pancreatic uptake determined by in vivo SPECT/CT and histological BCM in biobreeding diabetes-prone rats with unilateral nephrectomy $(\mathrm{r}=$ 0.89) (108). Furthermore, dual probe injection methods have been examined to distinguish the pancreas from other abdominal organs. ${ }^{123}$ I-labeled L-phenylalanine and ${ }^{99 \mathrm{~m}} \mathrm{Tc}$-demobesin- 4 have been employed with ${ }^{111}$ In-labeled exendin-3, improving the correlation between ex vivo pancreatic uptake and that determined by in vivo SPECT image analysis $(r=0.83$ and $r=0.92$, respectively) $(71,109)$. However, these methods still required simultaneous nephrectomy, which might alter probe biodistribution, and could not adequately cover the volume of pancreatic regions of interest for BCM evaluation of the whole pancreas $(71,101,109)$. A method for the in vivo SPECT imaging analysis of mice without the need for nephrectomy or a secondary probe has subsequently been developed using [Lys ${ }^{12}\left({ }^{111}\right.$ In-BnDTPA-Ahx)] exendin-4 (101). The exclusion of the peripheral space $2.7 \mathrm{~mm}$ from the kidney surface on SPECT/CT images can remove the influence of renal uptake and can cover over $40 \%$ of the entire pancreatic volume, which provides a reliable estimate of the mean uptake value for the entire pancreas (101). According to this method, the correlation between ex vivo pancreatic uptake and that determined by ex vivo SPECT scans was almost perfect $(\mathrm{r}=0.99)$. In vivo SPECT imaging analysis demonstrated good correlation between pancreatic uptake determined by in vivo SPECT scans and histological BCM in NOD $(\mathrm{r}=0.89)(102)$ and $\mathrm{db} / \mathrm{db}$ mice $(\mathrm{r}=0.93$ and 0.84$)(35,103)$. These correlations were higher or comparable to those achieved by methods that require nephrectomy and secondary probes.

As for clinical research, SPECT scans using $\left[\operatorname{Lys}^{40}\left(\left[{ }^{111} \mathrm{In}\right]\right.\right.$ DTPA)] exendin-3 have been performed on patients with type 1 diabetes mellitus (12). In this study, the pancreatic uptake estimated with a SPECT imaging analysis showed an approximately $60 \%$ reduction in the patients with type 1 diabetes compared with the healthy participants. However, the pancreatic probe uptake between the two groups overlapped, and high interindividual variations were observed. Further clinical studies for non-invasive BCM evaluation are therefore warranted, including with other exendin- 4 derivatives and PET imaging.

\section{APPLICATION OF GLP-1R-TARGETED IMAGING IN DIABETES MELLITUS}

The establishment of in vivo SPECT imaging analysis using [Lys ${ }^{12}$ $\left({ }^{111}\right.$ In-BnDTPA-Ahx $)$ exendin-4 has enabled the longitudinal observation of BCM changes in diabetic model mice with and without interventions. In NOD mice, a reduction in pancreatic probe uptake in in vivo SPECT images was longitudinally observed in the mice that developed hyperglycemia, whereas no significant changes in pancreatic probe uptake in the in vivo SPECT images were observed in the mice that did not develop hyperglycemia (102). In $\mathrm{db} / \mathrm{db}$ mice, longitudinal in vivo SPECT observations revealed a spontaneous reduction in pancreatic probe uptake $(35,103)$ and that diet-restriction attenuated the reduction in BCM loss (35). In vivo SPECT observations also observed that canagliflozin (a sodium glucose transporter-2 inhibitor) and DS-8500a (a G protein-coupled receptor 119 agonist) attenuated the progression of BCM loss in $\mathrm{db} / \mathrm{db}$ mice $(34,103)$. Although chronic hyperglycemia might affect probe uptake via changes in GLP-1R expression levels on the $\beta$-cell membrane surface (110), the pancreatic uptake of $\left[\operatorname{Lys}^{12}\left({ }^{111} \mathrm{In}\right.\right.$ BnDTPA-Ahx)] exendin-4 in SPECT images could replicate the BCM relationship among these model mice with different glycemic states $(35,102,103)$. Moreover, the pancreatic uptake of $\left[\right.$ Lys $^{12}\left({ }^{111}\right.$ In-BnDTPA-Ahx $\left.)\right]$ exendin-4 maintained a linear correlation with histological $\mathrm{BCM}$, even among diabetic and non-diabetic RCS-10 mice (11). The pancreatic uptake of the probe consists of combined probe intensities of cell-surface bindings to GLP-1R and intracellular accumulations. Consequently, it doesn't simply reflect cell-surface GLP-1R expression level changes but also it can be largely affected by probe internalization and accumulation in pancreatic tissues, which may contribute to maintain a linear correlation with BCM. ${ }^{111}$ In-exendin-4 SPECT/CT is therefore useful for the non-invasive longitudinal investigation of BCM in vivo and can help reveal the BCM preservation effects of each intervention.

The monitoring of transplanted islet grafts is another potential application of GLP-1R-targeted imaging (111). In rodents with intramuscular islet transplantation, $\left[\operatorname{Lys}^{40}\left(\left[{ }^{111}\right.\right.\right.$ In $]$ DTPA $\left.)\right]$ exendin3 showed non-invasive visualization of islet grafts and quantification of islet graft volume on SPECT $(13,110)$. Although 
exendin-3 probe uptake in islet grafts might be affected by the glycemic state via GLP-1R expression (presumably due to the small number of islets in a graft), the linear correlation between probe uptake and islet graft volume was maintained (110). In mice that underwent intraportal islet transplantation, ${ }^{68} \mathrm{Ga}-\mathrm{DO} 3 \mathrm{~A}-\mathrm{VS}$ Cys ${ }^{40}$-exendin-4 PET visualized human transplanted islets in the liver (112). As a clinical report of a patient with the autologous transplanted islets in the left brachioradialis muscle, $\left[\mathrm{Lys}^{40}(\mathrm{Ahx}-\right.$ DTPA- ${ }^{111}$ In)NH2] exendin-4 SPECT demonstrated focal accumulation in the left forearm at the site of islet transplantation (113). These results suggest the major potential of non-invasive monitoring of islet grafts; further investigations are expected for future clinical applications.

Lastly, GLP-1R-targeted imaging can be employed to better select antidiabetic drugs including GLP-1R agonists. The pancreatic uptake of [Lys ${ }^{12}\left({ }^{111}\right.$ In-BnDTPA-Ahx $\left.)\right]$ exendin-4 is reflected in the in vivo glucose-lowering effects of dulaglutide in diabetic RCS-10 mice, which suggests that the pancreatic uptake value could predict responders and non-responders to dulaglutide therapy (11). Given that the probe's pancreatic uptake was significantly correlated with BCM and GLP-1R mRNA expression, GLP-1R-targeted imaging can be a predictive indicator of the efficacy of not only GLP-1R agonists but also other antidiabetic drugs.

\section{CONCLUSIONS AND FURTHER PERSPECTIVES}

The last two decades of research have achieved remarkable advances in non-invasive $\beta$-cell imaging and BCM evaluation, including the discovery of probe target molecules, the development of suitable radioisotope-labeled chemically modified probes, and the establishment of an analysis method for image-based signals using SPECT and PET. In particular, exendin-4 based derivatives for SPECT and PET appear to be promising candidates for non-invasive BCM evaluations. At least in rodents, [Lys ${ }^{12}\left({ }^{111} \mathrm{In}-\mathrm{BnDTPA}-\mathrm{Ahx}\right)$ ] exendin-4 SPECT is a useful tool for in vivo longitudinal BCM monitoring. Further clinical investigation is necessary to meet the medical needs of BCM evaluation in diabetes. Although various novel chemical modifications and structures of exendin peptides have yet to be investigated, further comparative studies including head-to-head comparisons among the candidate probes and techniques are warranted to standardize non-invasive BCM evaluation methods using GLP-1R-targeted imaging techniques.

\section{AUTHOR CONTRIBUTIONS}

TM performed a literature search and wrote and edited the manuscript. HF contributed to the plan and discussion. NI reviewed and edited the manuscript. All authors contributed to the article and approved the submitted version.

\section{FUNDING}

This work was supported by grants from the Japan Foundation for Applied Enzymology (Front Runner of Future Diabetes Research) (to TM), MSD Life Science Foundation (to TM), and Manpei Suzuki Diabetes Foundation (to NI).

\section{REFERENCES}

1. International Diabetes Federation. Idf Diabetes Atlas. 9th ed. Brussels, Belgium: International Diabetes Federation (2019). Available at: http:// www.idf.org/diabetesatlas.

2. Rhodes CJ. Type 2 Diabetes-A Matter of Beta-Cell Life and Death? Science (2005) 307:380-4. doi: 10.1126/science.1104345

3. Kendall DM, Cuddihy RM, Bergenstal RM. Clinical Application of IncretinBased Therapy: Therapeutic Potential, Patient Selection and Clinical Use. Am J Med (2009) 122(Suppl):S37-50. doi: 10.1016/j.amjmed.2009.03.015

4. Weir GC, Gaglia J, Bonner-Weir S. Inadequate $\beta$-Cell Mass Is Essential for the Pathogenesis of Type 2 Diabetes. Lancet Diabetes Endocrinol (2020) 8:249-56. doi: 10.1016/S2213-8587(20)30022-X

5. Imagawa A, Hanafusa T, Miyagawa J, Matsuzawa Y. A Novel Subtype of Type 1 Diabetes Mellitus Characterized by a Rapid Onset and an Absence of Diabetes-Related Antibodies. Osaka Iddm Study Group. N Engl J Med (2000) 342:301-7. doi: 10.1056/NEJM200002033420501

6. Tuomi T, Groop LC, Zimmet PZ, Rowley MJ, Knowles W, Mackay IR. Antibodies to Glutamic Acid Decarboxylase Reveal Latent Autoimmune Diabetes Mellitus in Adults With a Non-Insulin-Dependent Onset of Disease. Diabetes (1993) 42:359-62. doi: 10.2337/diab.42.2.359

7. Kobayashi T, Itoh T, Kosaka K, Sato K, Tsuji K. Time Course of Islet Cell Antibodies and Beta-Cell Function in Non-Insulin-Dependent Stage of Type I Diabetes. Diabetes (1987) 36:510-7. doi: 10.2337/diab.36.4.510

8. Yamada Y, Fukuda K, Fujimoto S, Hosokawa M, Tsukiyama K, Nagashima $\mathrm{K}$, et al. SUIT, Secretory Units of Islets in Transplantation: An Index for

Therapeutic Management of Islet Transplanted Patients and Its Application to Type 2 Diabetes. Diabetes Res Clin Pract (2006) 74:222-6. doi: 10.1016/ j.diabres.2006.03.030

9. U.K. Prospective Diabetes Study Group. U.K. Prospective Diabetes Study 16. Overview of 6 Years' Therapy of Type II Diabetes: A Progressive Disease. Diabetes (1995) 44:1249-58. doi: 10.2337/diab.44.11.1249

10. Butler AE, Janson J, Bonner-Weir S, Ritzel R, Rizza RA, Butler PC. Beta-Cell Deficit and Increased Beta-Cell Apoptosis in Humans With Type 2 Diabetes. Diabetes (2003) 52:102-10. doi: 10.2337/diabetes.52.1.102

11. Murakami T, Fujimoto H, Fujita N, Hamamatsu K, Yabe D, Inagaki N Association of Glucagon-Like Peptide-1 Receptor-Targeted Imaging Probe With In Vivo Glucagon-Like Peptide-1 Receptor Agonist Glucose-Lowering Effects. J Diabetes Investig (2020) 11:1448-56. doi: 10.1111/jdi.13281

12. Brom M, Woliner-van der Weg W, Joosten L, Frielink C, Bouckenooghe T, Rijken P, et al. Non-Invasive Quantification of the Beta Cell Mass by SPECT With ${ }^{111}$ in-Labelled Exendin. Diabetologia (2014) 57:950-9. doi: 10.1007/ s00125-014-3166-3

13. Eter WA, van der Kroon I, Andralojc K, Buitinga M, Willekens SMA, Frielink C, et al. Non-Invasive In Vivo Determination of Viable Islet Graft Volume by ${ }^{111}$ In-Exendin-3. Sci Rep (2017) 7:7232. doi: 10.1038/s41598017-07815-3

14. Kimura H, Fujita N, Kanbe K, Matsuda H, Watanabe H, Arimitsu K, et al. Synthesis and Biological Evaluation of an 111In-Labeled Exendin-4 Derivative as a Single-Photon Emission Computed Tomography Probe for Imaging Pancreatic $\beta$-Cells. Bioorg Med Chem (2017) 25:5772-8. doi: 10.1016/j.bmc.2017.09.005 
15. Kimura H, Ogawa Y, Fujimoto H, Mukai E, Kawashima H, Arimitsu K, et al. Evaluation of 18F-Labeled Exendin(9-39) Derivatives Targeting GlucagonLike Peptide-1 Receptor for Pancreatic $\beta$-Cell Image. Bioorg Med Chem (2018) 26:463-9. doi: 10.1016/j.bmc.2017.12.007

16. Eizirik DL, Pasquali L, Cnop M. Pancreatic $\beta$-Cells in Type 1 and Type 2 Diabetes Mellitus: Different Pathways to Failure. Nat Rev Endocrinol (2020) 16:349-62. doi: 10.1038/s41574-020-0355-7

17. Demine S, Schulte ML, Territo PR, Eizirik DL. Beta Cell Imaging-From PreClinical Validation to First in Man Testing. Int J Mol Sci (2020) 21:7274. doi: 10.3390/ijms21197274

18. Oram RA, Sims EK, Evans-Molina C. Beta Cells in Type 1 Diabetes: Mass and Function; Sleeping or Dead? Diabetologia (2019) 62:567-77. doi: 10.1007/s00125-019-4822-4

19. Cho JH, Kim JW, Shin JA, Shin J, Yoon KH. $\beta$-Cell Mass in People With Type 2 Diabetes. J Diabetes Investig (2011) 2:6-17. doi: 10.1111/j.20401124.2010.00072.x

20. Tiedge M. Inside the Pancreas: Progress and Challenges of Human Beta Cell Mass Quantification. Diabetologia (2014) 57:856-9. doi: 10.1007/s00125014-3206-Z

21. Wang L, Lovejoy NF, Faustman DL. Persistence of Prolonged C-Peptide Production in Type 1 Diabetes as Measured With an Ultrasensitive Cpeptide Assay. Diabetes Care (2012) 35:465-70. doi: 10.2337/dc11-1236

22. Williams GM, Long AE, Wilson IV, Aitken RJ, Wyatt RC, McDonald TJ, et al. Beta Cell Function and Ongoing Autoimmunity in Long-Standing, Childhood Onset Type 1 Diabetes. Diabetologia (2016) 59:2722-6. doi: 10.1007/s00125-016-4087-0

23. Panzer JK, Hiller H, Cohrs CM, Almaça J, Enos SJ, Beery M, et al. Pancreas Tissue Slices From Organ Donors Enable in Situ Analysis of Type 1 Diabetes Pathogenesis. JCI Insight (2020) 5:e134525. doi: 10.1172/jci.insight.134525

24. Nakamura T, Fujikura J, Inagaki N. Advancements in Transplantation Therapy for Diabetes: Pancreas, Islet and Stem Cell. J Diabetes Investig (2021) 12:143-5. doi: 10.1111/jdi.13358

25. Brennan DC, Kopetskie HA, Sayre PH, Alejandro R, Cagliero E, Shapiro $\mathrm{AM}$, et al. Long-Term Follow-Up of the Edmonton Protocol of Islet Transplantation in the United States. Am J Transplant (2016) 16:509-17. doi: 10.1111/ajt.13458

26. Hering BJ, Kandaswamy R, Ansite JD, Eckman PM, Nakano M, Sawada T, et al. Single-Donor, Marginal-Dose Islet Transplantation in Patients With Type 1 Diabetes. JAMA (2005) 293:830-5. doi: 10.1001/jama.293.7.830

27. Hering BJ, Clarke WR, Bridges ND, Eggerman TL, Alejandro R, Bellin MD, et al. Phase 3 Trial of Transplantation of Human Islets in Type 1 Diabetes Complicated by Severe Hypoglycemia. Diabetes Care (2016) 39:1230-40. doi: $10.2337 / \mathrm{dc} 15-1988$

28. Kieffer TJ, Woltjen K, Osafune K, Yabe D, Inagaki N. Beta-Cell Replacement Strategies for Diabetes. J Diabetes Investig (2017) 9:457-63. doi: 10.1111/ jdi. 12758

29. Agulnick AD, Ambruzs DM, Moorman MA, Bhoumik A, Cesario RM, Payne JK, et al. Insulin-Producing Endocrine Cells Differentiated In Vitro From Human Embryonic Stem Cells Function in Macroencapsulation Devices In Vivo. Stem Cells Transl Med (2015) 4:1214-22. doi: 10.5966/sctm.2015-0079

30. Bruin JE, Rezania A, Xu J, Narayan K, Fox JK, O’Neil JJ, et al. Maturation and Function of Human Embryonic Stem Cell-Derived Pancreatic Progenitors in Macroencapsulation Devices Following Transplant Into Mice. Diabetologia (2013) 56:1987-98. doi: 10.1007/s00125-013-2955-4

31. Sakuraba H, Mizukami H, Yagihashi N, Wada R, Hanyu C, Yagihashi S. Reduced Beta-Cell Mass and Expression of Oxidative Stress-Related DNA Damage in the Islet of Japanese Type II Diabetic Patients. Diabetologia (2002) 45:85-96. doi: 10.1007/s125-002-8248-Z

32. Yoon KH, Ko SH, Cho JH, Lee JM, Ahn YB, Song KH, et al. Selective BetaCell Loss and Alpha-Cell Expansion in Patients With Type 2 Diabetes Mellitus in Korea. J Clin Endocrinol Metab (2003) 88:2300-8. doi: 10.1210/ jc.2002-020735

33. Klöppel G, Löhr M, Habich K, Oberholzer M, Heitz PU. Islet Pathology and the Pathogenesis of Type 1 and Type 2 Diabetes Mellitus Revisited. Surv Synth Pathol Res (1985) 4:110-25. doi: 10.1159/000156969

34. Rahier J, Guiot Y, Goebbels RM, Sempoux C, Henquin JC. Pancreatic BetaCell Mass in European Subjects With Type 2 Diabetes. Diabetes Obes Metab (2008) 10(Suppl 4):32-42. doi: 10.1111/j.1463-1326.2008.00969.x
35. Murakami T, Fujimoto H, Fujita N, Hamamatsu K, Matsumoto K, Inagaki N. Noninvasive Evaluation of GPR119 Agonist Effects on $\beta$-Cell Mass in Diabetic Male Mice Using 111In-Exendin-4 SPECT/CT. Endocrinology (2019) 160:2959-68. doi: 10.1210/en.2019-00556

36. Da Silva Xavier G. The Cells of the Islets of Langerhans. J Clin Med (2018) 7:54. doi: 10.3390/jcm7030054

37. Andralojc K, Srinivas M, Brom M, Joosten L, de Vries IJ, Eizirik DL, et al. Obstacles on the Way to the Clinical Visualisation of Beta Cells: Looking for the Aeneas of Molecular Imaging to Navigate Between Scylla and Charybdis. Diabetologia (2012) 55:1247-57. doi: 10.1007/s00125-012-2491-7

38. Khalil MM, Tremoleda JL, Bayomy TB, Gsell W. Molecular SPECT Imaging: An Overview. Int J Mol Imaging (2011) 2011:796025. doi: 10.1155/2011/ 796025

39. Velikyan I, Eriksson O. Advances in GLP-1 Receptor Targeting Radiolabeled Agent Development and Prospective of Theranostics. Theranostics (2020) 10:437-61. doi: 10.7150/thno.38366

40. Kimura H, Matsuda H, Fujimoto H, Arimitsu K, Toyoda K, Mukai E, et al. Synthesis and Evaluation of 18F-Labeled Mitiglinide Derivatives as Positron Emission Tomography Tracers for $\beta$-Cell Imaging. Bioorg Med Chem (2014) 22:3270-8. doi: 10.1016/j.bmc.2014.04.059

41. Wängler B, Schneider S, Thews O, Schirrmacher E, Comagic S, Feilen P, et al. Synthesis and Evaluation of (s)-2-(2-[18F]fluoroethoxy)-4-([3-methyl1-(2-piperidin-1-yl-phenyl)-butyl-carbamoyl]-methyl)-benzoic Acid ([18F] Repaglinide): A Promising Radioligand for Quantification of Pancreatic Beta-Cell Mass With Positron Emission Tomography (PET). Nucl Med Biol (2004) 31:639-47. doi: 10.1016/j.nucmedbio.2004.01.007

42. Arimitsu K, Yagi Y, Koshino K, Nishito Y, Higuchi T, Yasui H, et al. Synthesis of ${ }^{18} \mathrm{~F}$-Labeled Streptozotocin Derivatives and an in-Vivo Kinetics Study Using Positron Emission Tomography. Bioorg Med Chem Lett (2020) 30:127400. doi: 10.1016/j.bmcl.2020.127400

43. Hernandez R, Graves SA, Gregg T, VanDeusen HR, Fenske RJ, Wienkes HN, et al. Radiomanganese PET Detects Changes in Functional $\beta$-Cell Mass in Mouse Models of Diabetes. Diabetes (2017) 66:2163-74. doi: 10.2337/db16-1285

44. Eriksson O, Johnström P, Cselenyi Z, Jahan M, Selvaraju RK, Jensen-Waern $\mathrm{M}$, et al. In Vivo Visualization of $\beta$-Cells by Targeting of GPR44. Diabetes (2018) 67:182-92. doi: 10.2337/db17-0764

45. Eriksson O. GPR44 as a Target for Imaging Pancreatic Beta-Cell Mass. Curr Diabetes Rep (2019) 19:49. doi: 10.1007/s11892-019-1164-z

46. Bini J, Sanchez-Rangel E, Gallezot JD, Naganawa M, Nabulsi N, Lim K, et al. PET Imaging of Pancreatic Dopamine $\mathrm{D}_{2}$ and $\mathrm{D}_{3}$ Receptor Density With ${ }^{11} \mathrm{C}-(+)-$ PHNO in Type 1 Diabetes. J Nucl Med (2020) 61:570-6. doi: $10.2967 /$ jnumed.119.234013

47. Eriksson O, Mintz A, Liu C, Yu M, Naji A, Alavi A. On the Use of $[18 \mathrm{~F}]$ DOPA as an Imaging Biomarker for Transplanted Islet Mass. Ann Nucl Med (2014) 28:47-52. doi: 10.1007/s12149-013-0779-4

48. Eriksson O, Espes D, Selvaraju RK, Jansson E, Antoni G, Sörensen J, et al. Positron Emission Tomography Ligand [11C]5-Hydroxy-Tryptophan can be Used as a Surrogate Marker for the Human Endocrine Pancreas. Diabetes (2014) 63:3428-37. doi: 10.2337/db13-1877

49. Espes D, Carlsson PO, Selvaraju RK, Rosestedt M, Cheung P, Ahlström H, et al. Longitudinal Assessment of ${ }^{11} \mathrm{C}-5$-Hydroxytryptophan Uptake in Pancreas After Debut of Type 1 Diabetes. Diabetes (2021) 70:966-75. doi: $10.2337 / \mathrm{db} 20-0776$

50. Carlbom L, Espes D, Lubberink M, Martinell M, Johansson L, Ahlström H, et al. [11C]5-Hydroxy-Tryptophan PET for Assessment of Islet Mass During Progression of Type 2 Diabetes. Diabetes (2017) 66:1286-92. doi: 10.2337/ db16-1449

51. Eriksson O, Selvaraju R, Eich T, Willny M, Brismar TB, Carlbom L, et al. Positron Emission Tomography to Assess the Outcome of Intraportal Islet Transplantation. Diabetes (2016) 65:2482-9. doi: 10.2337/db16-0222

52. Normandin MD, Petersen KF, Ding YS, Lin SF, Naik S, Fowles K, et al. In Vivo Imaging of Endogenous Pancreatic $\beta$-Cell Mass in Healthy and Type 1 Diabetic Subjects Using 18F-Fluoropropyl-Dihydrotetrabenazine and PET. J Nucl Med (2012) 53:908-16. doi: 10.2967/jnumed.111.100545

53. Freeby MJ, Kringas P, Goland RS, Leibel RL, Maffei A, Divgi C, et al. CrossSectional and Test-Retest Characterization of PET With [(18)F]FP(+)-DTBZ for $\beta$ Cell Mass Estimates in Diabetes. Mol Imaging Biol (2016) 18:292-301. doi: 10.1007/s11307-015-0888-7 
54. Mukai E, Toyoda K, Kimura H, Kawashima H, Fujimoto H, Ueda M, et al. GLP-1 Receptor Antagonist as a Potential Probe for Pancreatic Beta-Cell Imaging. Biochem Biophys Res Commun (2009) 389:523-6. doi: 10.1016/ j.bbrc.2009.09.014

55. Gotthardt M, Lalyko G, van Eerd-Vismale J, Keil B, Schurrat T, Hower M, et al. A New Technique for In Vivo Imaging of Specific GLP-1 Binding Sites: First Results in Small Rodents. Regul Pept (2006) 137:162-7. doi: 10.1016/ j.regpep.2006.07.005

56. Neo CWY, Ciaramicoli LM, Soetedjo AAP, Teo AKK, Kang NY. A New Perspective of Probe Development for Imaging Pancreatic Beta Cell In Vivo. Semin Cell Dev Biol (2020) 103:3-13. doi: 10.1016/j.semcdb.2020.01.009

57. Schneider S, Feilen PJ, Schreckenberger M, Schwanstecher M, Schwanstecher C, Buchholz HG, et al. In Vitro and In Vivo Evaluation of Novel Glibenclamide Derivatives as Imaging Agents for the non-Invasive Assessment of the Pancreatic Islet Cell Mass in Animals and Humans. Exp Clin Endocrinol Diabetes (2005) 113:388-95. doi: 10.1055/s-2005-865711

58. Oh CS, Kohanim S, Kong FL, Song HC, Huynh N, Mendez R, et al. Sulfonylurea Receptor as a Target for Molecular Imaging of Pancreas Beta Cells With (99m)Tc-DTPA-Glipizide. Ann Nucl Med (2012) 26:253-61. doi: 10.1007/s12149-011-0569-9

59. Rubí B, Ljubicic S, Pournourmohammadi S, Carobbio S, Armanet M, Bartley C, et al. Dopamine D2-Like Receptors are Expressed in Pancreatic Beta Cells and Mediate Inhibition of Insulin Secretion. J Biol Chem (2005) 280:3682432. doi: 10.1074/jbc.M505560200

60. Tessonnier L, Sebag F, Ghander C, De Micco C, Reynaud R, Palazzo FF, et al. Limited Value of 18F-F-DOPA PET to Localize Pancreatic Insulin-Secreting Tumors in Adults With Hyperinsulinemic Hypoglycemia. J Clin Endocrinol Metab (2010) 95:303-7. doi: 10.1210/jc.2009-1357

61. Di Gialleonardo V, Signore A, Scheerstra EA, Visser AK, van Waarde A, Dierckx RA, et al. 11C-Hydroxytryptophan Uptake and Metabolism in Endocrine and Exocrine Pancreas. J Nucl Med (2012) 53:1755-63. doi: 10.2967/jnumed.112.104117

62. Jodal A, Schibli R, Béhé M. Targets and Probes for non-Invasive Imaging of ß-Cells. Eur J Nucl Med Mol Imaging (2017) 44:712-27. doi: 10.1007/s00259016-3592-1

63. Freeby M, Ichise M, Harris PE. Vesicular Monoamine Transporter, Type 2 (VMAT2) Expression as It Compares to Insulin and Pancreatic Polypeptide in the Head, Body and Tail of the Human Pancreas. Islets (2012) 4:393-7. doi: 10.4161/isl.22995

64. Saisho Y, Harris PE, Butler AE, Galasso R, Gurlo T, Rizza RA, et al. Relationship Between Pancreatic Vesicular Monoamine Transporter 2 (VMAT2) and Insulin Expression in Human Pancreas. J Mol Histol (2008) 39:543-51. doi: 10.1007/s10735-008-9195-9

65. Tornehave D, Kristensen P, Rømer J, Knudsen LB, Heller RS. Expression of the GLP-1 Receptor in Mouse, Rat, and Human Pancreas. J Histochem Cytochem (2008) 56:841-51. doi: 10.1369/jhc.2008.951319

66. Eriksson O, Rosenström U, Selvaraju RK, Eriksson B, Velikyan I. Species Differences in Pancreatic Binding of DO3A-vs-Cys ${ }^{40}$-Exendin4. Acta Diabetol (2017) 54:1039-45. doi: 10.1007/s00592-017-1046-2

67. Kieffer TJ, McIntosh CH, Pederson RA. Degradation of Glucose-Dependent Insulinotropic Polypeptide and Truncated Glucagon-Like Peptide 1 In Vitro and In Vivo by Dipeptidyl Peptidase IV. Endocrinology (1995) 136:3585-96. doi: 10.1210/endo.136.8.7628397

68. Eng J, Kleinman WA, Singh L, Singh G, Raufman JP. Isolation and Characterization of Exendin-4, an Exendin-3 Analogue, From Heloderma Suspectum Venom. Further Evidence for an Exendin Receptor on Dispersed Acini From Guinea Pig Pancreas. J Biol Chem (1992) 267:7402-5. doi: 10.1016/S0021-9258(18)42531-8

69. Gotthardt M, Fischer M, Naeher I, Holz JB, Jungclas H, Fritsch HW, et al. Use of the Incretin Hormone Glucagon-Like Peptide-1 (GLP-1) for the Detection of Insulinomas: Initial Experimental Results. Eur J Nucl Med Mol Imaging (2002) 29:597-606. doi: 10.1007/s00259-002-0761-1

70. Brom M, Joosten L, Oyen WJ, Gotthardt M, Boerman OC. Improved Labelling of DTPA- and DOTA-conjugated Peptides and Antibodies With 111In in HEPES and MES Buffer. EJNMMI Res (2012) 2:4. doi: 10.1186/ 2191-219X-2-4

71. Mathijs I, Xavier C, Peleman C, Caveliers V, Brom M, Gotthardt M, et al. A Standardized Method for In Vivo Mouse Pancreas Imaging and
Semiquantitative $\beta$ Cell Mass Measurement by Dual Isotope SPECT. Mol Imaging Biol (2015) 17:58-66. doi: 10.1007/s11307-014-0771-y

72. Brom M, Oyen WJ, Joosten L, Gotthardt M, Boerman OC. 68Ga-Labelled exendin-3, a New Agent for the Detection of Insulinomas With PET. Eur J Nucl Med Mol Imaging (2010) 37:1345-55. doi: 10.1007/s00259-009-1363-y

73. Waser B, Reubi JC. Value of the Radiolabelled GLP-1 Receptor Antagonist Exendin(9-39) for Targeting of GLP-1 Receptor-Expressing Pancreatic Tissues in Mice and Humans. Eur J Nucl Med Mol Imaging (2011) 38:1054-8. doi: 10.1007/s00259-010-1701-0

74. Waser B, Reubi JC. Radiolabelled GLP-1 Receptor Antagonist Binds to GLP1 Receptor-Expressing Human Tissues. Eur J Nucl Med Mol Imaging (2014) 41:1166-71. doi: 10.1007/s00259-013-2684-4

75. Kimura H, Matsuda H, Ogawa Y, Fujimoto H, Toyoda K, Fujita N, et al. Development of ${ }^{111}$ In-Labeled Exendin(9-39) Derivatives for Single-Photon Emission Computed Tomography Imaging of Insulinoma. Bioorg Med Chem (2017) 25:1406-12. doi: 10.1016/j.bmc.2016.12.051

76. Runge S, Thøgersen H, Madsen K, Lau J, Rudolph R. Crystal Structure of the Ligand-Bound Glucagon-Like Peptide-1 Receptor Extracellular Domain. J Biol Chem (2008) 283:11340-7. doi: 10.1074/jbc.M708740200

77. Brom M, Joosten L, Oyen WJ, Gotthardt M, Boerman OC. Radiolabelled GLP-1 Analogues for In Vivo Targeting of Insulinomas. Contrast Media Mol Imaging (2012) 7:160-6. doi: 10.1002/cmmi.475

78. Wang Y, Lim K, Normandin M, Zhao X, Cline GW, Ding YS. Synthesis and Evaluation of [18F]Exendin (9-39) as a Potential Biomarker to Measure Pancreatic $\beta$-Cell Mass. Nucl Med Biol (2012) 39:167-76. doi: 10.1016/ j.nucmedbio.2011.07.011

79. Christ E, Wild D, Ederer S, Béhé M, Nicolas G, Caplin ME, et al. GlucagonLike Peptide-1 Receptor Imaging for the Localisation of Insulinomas: A Prospective Multicentre Imaging Study. Lancet Diabetes Endocrinol (2013) 1:115-22. doi: 10.1016/S2213-8587(13)70049-4

80. Wild D, Wicki A, Mansi R, Béhé M, Keil B, Bernhardt P, et al. Exendin-4-based Radiopharmaceuticals for Glucagonlike Peptide-1 Receptor PET/CT and SPECT/CT. J Nucl Med (2010) 51:1059-67. doi: 10.2967/jnumed.110.074914

81. Jodal A, Lankat-Buttgereit B, Brom M, Schibli R, Béhé M. A Comparison of Three (67/68)Ga-Labelled Exendin-4 Derivatives for $\beta$-Cell Imaging on the GLP-1 Receptor: The Influence of the Conjugation Site of NODAGA as Chelatorga. EJNMMI Res (2014) 4:31. doi: 10.1186/s13550-014-0031-9

82. Läppchen T, Tönnesmann R, Eersels J, Meyer PT, Maecke HR, Rylova SN. Radioiodinated Exendin-4 Is Superior to the Radiometal-Labelled GlucagonLike Peptide-1 Receptor Probes Overcoming Their High Kidney Uptake. PLoS One (2017) 12:e0170435. doi: 10.1371/journal.pone.0170435

83. Selvaraju RK, Velikyan I, Johansson L, Wu Z, Todorov I, Shively J, et al. In Vivo Imaging of the Glucagonlike Peptide 1 Receptor in the Pancreas With 68Ga-Labeled DO3A-Exendin-4. J Nucl Med (2013) 54:1458-63. doi: $10.2967 /$ jnumed.112.114066

84. Zhang M, Jacobson O, Kiesewetter DO, Ma Y, Wang Z, Lang L, et al. Improving the Theranostic Potential of Exendin 4 by Reducing the Renal Radioactivity Through Brush Border Membrane Enzyme-Mediated Degradation. Bioconjug Chem (2019) 30:1745-53. doi: 10.1021/ acs.bioconjchem.9b00280

85. Bauman A, Valverde IE, Fischer CA, Vomstein S, Mindt TL. Development of 68Ga- and $89 \mathrm{Zr}$-Labeled Exendin- 4 as Potential Radiotracers for the Imaging of Insulinomas by PET. J Nucl Med (2015) 56:1569-74. doi: $10.2967 /$ jnumed.115.159186

86. Eriksson O, Velikyan I, Selvaraju RK, Kandeel F, Johansson L, Antoni G, et al. Detection of Metastatic Insulinoma by Positron Emission Tomography With [(68)Ga] exendin-4-a Case Report. J Clin Endocrinol Metab (2014) 99:1519-24. doi: 10.1210/jc.2013-3541

87. Antwi K, Fani M, Nicolas G, Rottenburger C, Heye T, Reubi JC, et al. Localization of Hidden Insulinomas With ${ }^{68} \mathrm{Ga}$-DOTA-Exendin-4 PET/CT: A Pilot Study. J Nucl Med (2015) 56:1075-8. doi: 10.2967/jnumed.115.157768

88. Luo Y, Pan Q, Yao S, Yu M, Wu W, Xue H, et al. Glucagon-Like Peptide-1 Receptor PET/CT With 68Ga-NOTA-exendin-4 for Detecting Localized Insulinoma: A Prospective Cohort Study. J Nucl Med (2016) 57:715-20. doi: 10.2967/jnumed.115.167445

89. Antwi K, Fani M, Heye T, Nicolas G, Rottenburger C, Kaul F, et al. Comparison of Glucagon-Like Peptide-1 Receptor (GLP-1R) PET/CT, SPECT/CT and $3 \mathrm{~T}$ MRI for the Localisation of Occult Insulinomas: 
Evaluation of Diagnostic Accuracy in a Prospective Crossover Imaging Study. Eur J Nucl Med Mol Imaging (2018) 45:2318-27. doi: 10.1007/ s00259-018-4101-5

90. Wu Z, Todorov I, Li L, Bading JR, Li Z, Nair I, et al. In Vivo Imaging of Transplanted Islets With 64Cu-DO3A-VS-Cys40-Exendin-4 by Targeting GLP-1 Receptor. Bioconjug Chem (2011) 22:1587-94. doi: 10.1021/bc200132t

91. Mikkola K, Yim CB, Fagerholm V, Ishizu T, Elomaa VV, Rajander J, et al. 64Cu- and 68Ga-Labelled [Nle(14),Lys(40)(Ahx-NODAGA)NH2]-exendin4 for Pancreatic Beta Cell Imaging in Rats. Mol Imaging Biol (2014) 16:25563. doi: 10.1007/s11307-013-0691-2

92. Wu Z, Liu S, Nair I, Omori K, Scott S, Todorov I, et al. (64)Cu Labeled Sarcophagine Exendin-4 for microPET Imaging of Glucagon Like Peptide-1 Receptor Expression. Theranostics (2014) 4:770-7. doi: 10.7150/thno.7759

93. Yue X, Kiesewetter DO, Guo J, Sun Z, Zhang X, Zhu L, et al. Development of a New Thiol Site-Specific Prosthetic Group and its Conjugation With [Cys (40)]-Exendin-4 for In Vivo Targeting of Insulinomas. Bioconjug Chem (2013) 24:1191-200. doi: 10.1021/bc400084u

94. Jansen TJP, van Lith SAM, Boss M, Brom M, Joosten L, Béhé M, et al. Exendin-4 Analogs in Insulinoma Theranostics. J Labelled Comp Radiopharm (2019) 62:656-72. doi: 10.1002/jlcr.3750

95. Wu H, Liang S, Liu S, Pan Y, Cheng D, Zhang Y. 18F-Radiolabeled GLP-1 Analog Exendin-4 for PET/CT Imaging of Insulinoma in Small Animals. Nucl Med Commun (2013) 34:701-8. doi: 10.1097/MNM.0b013e3283614187

96. Dialer LO, Jodal A, Schibli R, Ametamey SM, Béhé M. Radiosynthesis and Evaluation of an ${ }^{18} \mathrm{~F}$-Labeled Silicon Containing Exendin-4 Peptide as a PET Probe for Imaging Insulinoma. EJNMMI Radiopharm Chem (2018) 3:1. doi: 10.1186/s41181-017-0036-6

97. Vegt E, Eek A, Oyen WJ, de Jong M, Gotthardt M, Boerman OC. Albumin-Derived Peptides Efficiently Reduce Renal Uptake of Radiolabelled Peptides. Eur J Nucl Med Mol Imaging (2010) 37:226-34. doi: 10.1007/s00259009-1239-1

98. Wang P, Yoo B, Yang J, Zhang X, Ross A, Pantazopoulos P, et al. Glp-1Rtargeting Magnetic Nanoparticles for Pancreatic Islet Imaging. Diabetes (2014) 63:1465-74. doi: 10.2337/db13-1543

99. Yue X, Yan X, Wu C, Niu G, Ma Y, Jacobson O, et al. One-Pot Two-Step Radiosynthesis of a New (18)F-Labeled Thiol Reactive Prosthetic Group and its Conjugate for Insulinoma Imaging. Mol Pharm (2014) 11:3875-84. doi: $10.1021 / \mathrm{mp} 5001857$

100. Babič A, Vinet L, Chellakudam V, Janikowska K, Allémann E, Lange N. Squalene-PEG-exendin as High-Affinity Constructs for Pancreatic Beta-Cells. Bioconjug Chem (2018) 29:2531-40. doi: 10.1021/acs.bioconjchem.8b00186

101. Hamamatsu K, Fujimoto H, Fujita N, Murakami T, Kimura H, Saji H, et al. Establishment of a Method for In-Vivo SPECT/CT Imaging Analysis of 111 In-labeled Exendin-4 Pancreatic Uptake in Mice Without the Need for Nephrectomy or a Secondary Probe. Nucl Med Biol (2018), 64-65:22-27. doi: 10.1016/j.nucmedbio.2018.06.002

102. Fujita N, Fujimoto H, Hamamatsu K, Murakami T, Kimura H, Toyoda K, et al. Noninvasive Longitudinal Quantification of $\beta$-Cell Mass With [ $\left.{ }^{111} \mathrm{In}\right]$-Labeled Exendin-4. FASEB J (2019) 33:11836-44. doi: 10.1096/fj.201900555RR

103. Hamamatsu K, Fujimoto H, Fujita N, Murakami T, Shiotani M, Toyoda K, et al. Investigation of the Preservation Effect of Canagliflozin on Pancreatic Beta Cell Mass Using SPECT/CT Imaging With ${ }^{111}$ In-Labeled Exendin-4. Sci Rep (2019) 9:18338. doi: 10.1038/s41598-019-54722-w

104. Eter WA, Parween S, Joosten L, Frielink C, Eriksson M, Brom M, et al. SpectOPT Multimodal Imaging Enables Accurate Evaluation of Radiotracers for $\beta$-Cell Mass Assessments. Sci Rep (2016) 6:24576. doi: 10.1038/srep24576
105. Brom M, Joosten L, Frielink C, Boerman O, Gotthardt M. (111)in-Exendin Uptake in the Pancreas Correlates With the $\beta$-Cell Mass and Not With the $\alpha$ Cell Mass. Diabetes (2015) 64:1324-8. doi: 10.2337/db14-1212

106. Joosten L, Brom M, Peeters H, Bos D, Himpe E, Bouwens L, et al. Measuring the Pancreatic $\beta$ Cell Mass In Vivo With Exendin SPECT During Hyperglycemia and Severe Insulitis. Mol Pharm (2019) 16:4024-30. doi: 10.1021/acs.molpharmaceut.9b00728

107. Willekens SM, Joosten L, Boerman OC, Balhuizen A, Eizirik DL, Gotthardt M, et al. Strain Differences Determine the Suitability of Animal Models for Noninvasive In Vivo Beta Cell Mass Determination With Radiolabeled Exendin. Mol Imaging Biol (2016) 18:705-14. doi: 10.1007/s11307-0160936-y

108. Brom M, Joosten L, Frielink C, Peeters H, Bos D, van Zanten M, et al. Validation of ${ }^{111}$ In-Exendin SPECT for the Determination of the $\beta$-Cell Mass in BioBreeding Diabetes-Prone Rats. Diabetes (2018) 67:2012-8. doi: $10.2337 / \mathrm{db} 17-1312$

109. van der Kroon I, Joosten L, Nock BA, Maina T, Boerman OC, Brom M, et al. Improved Quantification of the Beta Cell Mass After Pancreas Visualization With ${ }^{99 \mathrm{~m}} \mathrm{Tc}$-demobesin-4 and Beta Cell Imaging With ${ }^{111}$ In-Exendin-3 in Rodents. Mol Pharm (2016) 13:3478-83. doi: 10.1021/acs.molpharmaceut.6b00495

110. Buitinga M, Cohrs CM, Eter WA, Claessens-Joosten L, Frielink C, Bos D, et al. Noninvasive Monitoring of Glycemia-Induced Regulation of GLP-1R Expression in Murine and Human Islets of Langerhans. Diabetes (2020) 69:2246-52. doi: $10.2337 / \mathrm{db} 20-0616$

111. Arifin DR, Bulte JWM. In Vivo Imaging of Pancreatic Islet Grafts in Diabetes Treatment. Front Endocrinol (Lausanne) (2021) 12:640117. doi: 10.3389/ fendo.2021.640117

112. Li J, Rawson J, Chea J, Tang W, Miao L, Sui F, et al. Evaluation of $\left[{ }^{68} \mathrm{Ga}\right]$ DO3A-VS-Cys ${ }^{40}$-exendin- 4 as a PET Probe for Imaging Human Transplanted Islets in the Liver. Sci Rep (2019) 9:5705. doi: 10.1038/ s41598-019-42172-3

113. Pattou F, Kerr-Conte J, Wild D. Glp-1-receptor Scanning for Imaging of Human Beta Cells Transplanted in Muscle. N Engl J Med (2010) 363:128990. doi: 10.1056/NEJMc1004547

Conflict of Interest: NI received clinical commissioned/joint research grants from Daiichi Sankyo, Terumo, and Drawbridge Inc.; speaker honoraria from Kowa, MSD, Astellas Pharma, Novo Nordisk Pharma, Ono Pharmaceutical, Nippon Boehringer Ingelheim, Takeda, Eli Lilly Japan, Sumitomo Dainippon Pharma, and Mitsubishi Tanabe Pharma; scholarship grants from Kissei Pharmaceutical, Sanofi, Daiichi Sankyo, Mitsubishi Tanabe Pharma, Takeda, Japan Tobacco, Kyowa Kirin, Sumitomo Dainippon Pharma, Astellas Pharma, MSD, Eli Lilly Japan, Ono Pharmaceutical, Sanwa Kagaku Kenkyusho, Nippon Boehringer Ingelheim, Novo Nordisk Pharma, Novartis Pharma, Teijin Pharma, and Life Scan Japan.

The remaining authors declare that the research was conducted in the absence of any commercial or financial relationships that could be construed as a potential conflict of interest.

Copyright (๑ 2021 Murakami, Fujimoto and Inagaki. This is an open-access article distributed under the terms of the Creative Commons Attribution License (CC BY). The use, distribution or reproduction in other forums is permitted, provided the original author(s) and the copyright owner(s) are credited and that the original publication in this journal is cited, in accordance with accepted academic practice. No use, distribution or reproduction is permitted which does not comply with these terms. 